\title{
Spatial Development of Local Bantik Community in
}

\section{Malalayang, Indonesia}

\author{
Pingkan Peggy Egam $^{1,2}$ and Nobuo Mishima ${ }^{1}$ \\ 1. Graduate School of Science and Engineering, Saga University, Saga 840-8502, Japan \\ 2. Department of Architecture, Sam Ratulangi University, Manado 95115, Indonesia
}

\begin{abstract}
The Proximity between the central business district and the settlement has led to many changes in the local Bantik community. These include changes in the function of settlements, population size, location of residence, and the movement of local culture. This study aims to examine the spatial changes that occur in local neighborhoods with a focus on the Bantik tribal community in Malalayang. Data were obtained from a series of field observations, questionnaires and structured interviews. This study conducted a series of analyses on spatial patterns, sociocultural factors and urban policy. The results show that the dynamic changes are natural and hard to avoid, since they are related to the community's needs and development of the city. In order to face the changes, adjustments in the values of the local community towards the settlement terms and conditions are necessary. In addition, an increase in internal resources for those local communities is needed.
\end{abstract}

Key words: Spatial changes, local community, city development, Bantik, Indonesia.

\section{Introduction}

Bantik tribal settlements in Malalayang are located in the administrative area of the city of Manado, North Sulawesi, concentrating in the coastal areas. Because the local Bantik community is the only one of its kind found in Manado today, this cultural wealth in Manado needs to be protected and maintained. This paper raised issues rehabilitation of local settlement as one of the city's potential by looking at a variety of spatial-physical changes that have occurred in the settlement. City development is related to high population growth and the growth of business in the boulevard that intersects the settlement area directly puts, pressures on the city, resulting in a dramatic change in the existence of local settlements. The Bantik community has been affected by three types of spatial or physical factors: spatial pressure, psychological pressure and economic pressure [1]. Based upon the data (Fig. 1), the Bantik population in

Corresponding author: Pingkan Peggy Egam, research fields: architecture and urban design. E-mail: epingkan@yahoo.com. the study area was in the minority or approximately $30.25 \%$ in 2008 . This number then declined to $25 \%$ in 2011 (Fig. 1) againts the total population in study area. This population decline also affected the spatial aspects of Bantik life. Functional space began to change from a settlement into a potential economic space. This functional change is not based solely on spatial expression, but rather on the expression of a functional fabric of created activities. Naturally, this situation is an unavoidable consequence of urban development but it needs to be addressed in order to maintain and improve the existence and quality of the community environment. The purpose of this study is to examine the development of spatial-physical processes that occur in local neighborhoods with a focus on the Bantik tribe in Malalayang. This research reveals factors that influence the process of societal change, which include rehabilitation strategies in anticipation of maintaining a local presence in city neighborhoods. This paper covers three main areas of analysis: (1) dynamics of the settlement relating to spatial aspects; (2) dynamics of culture in community 


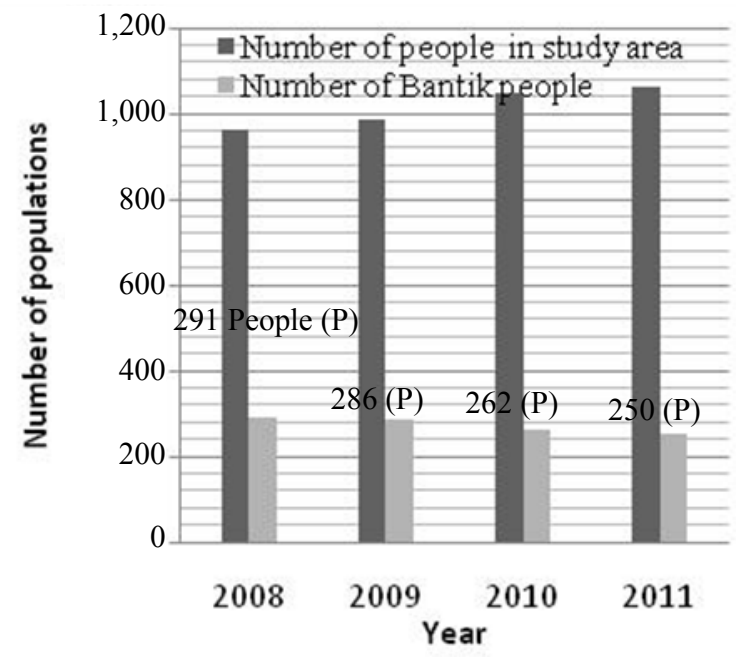

Fig. 1 People number in study area.

activities; (3) the drivers of spatial change. This study deals with Bantik population growth and their attitudes relating to community atmosphere and urban policy.

\section{Literature Review}

\subsection{Overview of the Bantik Tribal Communities}

The Bantik tribe is one of the ethnic groups present in Minahasa. Previously, the provincial capital of Manado in north Sulawesi was included in the administrative area of Minahasa. The Bantik are descendants of the Toda Boirluminutu who migrated to the island of Panimbulrang. Furthermore, after this group had been settled for the long term, they called themselves a Bantik society $[2,3]$. As the result of an earthquake, the Panimbulrang Island sank $[4,5]$. Moreover, as a result of tribal turmoil, Bantik societies were divided into seven groups, one of which occupied Bantik Mountain. From this mountain, they moved down to the area of Bahu that is located in southern Manado and now occupy both the frontage road of Malalayang and the coastal areas. This location was originally called the Minanga Village and is known as the native community of the Bantik in Malalayang. It is not known exactly when the village of Minanga was founded (Before the village of Minanga was founded, on the Mandarlaeng River bridge in the village, the words "ANNO 1886 Malalayang" were written. Based on these indications, the village Minanga probably existed prior to1886).

\subsection{Spatial Patterns and Regional Growth}

Spatial patterning relates to space in neighborhoods, homes, and other structures that accumulate as the result of population growth in society [6]. Spatial patterning is not only associated with physical space but also to humans and their activities. Studying the characteristics of dwellings (objects) and dwellers (users) is essential for determining the actual reasons behind development [7]. Since they are closely related to economic factors [8], the movement of communities or changes in their function visualization are difficult to avoid.

Urban spatial structure is not defined by one factor, but rather by comprehensive and complex factors that are influenced by historical and traditional elements [9]. The criteria for assessing a city's ability can be viewed from the perspective of its potential. Strategic geographical location strongly supports the accelerated development of the region rather than isolating it. Other studies conducted in Karioko by Swai and Deguchi show the influence of colonial policies on the evolving process and growth of urban structures in Dar es Salaam, Tanzania [9]. In addition, Rumi said that the degradation of cultural heritage was caused by informal urbanization [10].

\section{Methodology}

Based on the existing data, the biggest physical changes in the Bantik settlements were visible along the main street and around the coast. Aspects of spatial change are reviewed not only physically but also culturally, including the behavior and mindset of the local community. The unit of observation comprised the area starting at the first cut path bordering the Wolter Mongisidi Shoulder River and extending to the Minanga Road. The units of analysis involve the characteristics of community-based 
cultural, spatial and physical factors as the driving aspects of development. This analysis is expected to reveal the dominant aspect of the drivers of growth and other forms of spatial development in the community.

Data were obtained through field observations, in-depth interviews in local communities and questionnaires. Other data were obtained from the statistics of Manado City. The urban environment is analyzed based on town hall policies and interventions on the development of physical space.

This study is based on the settlements of Bantik tribal societies in Malalayang. Bantik settlements are scattered within the urban villages of Malalayang 1, Malalayang 1 East, and Malalayang 1 West. The highest population concentration is in Malalayang 1, followed by Malalayang 1 East. The total area of Malalayang 1 is 900 ha, of which an area of 780,245 ha is settled. Based on data from the village office of Malalayang 1 in 2012, there were 2,225 families. Of 8,272 inhabitants, 4,156 were male and 4,136 were female. Considering sub-districts 7 and 8 as a single observation unit (Fig. 2) with a total population of 632, there exist 191 heads of households in a population of 308 men and 324 women. The number of households in sub-district 8 is 105 . Of 416 people, 214 are men and 202 are women. From a total Bantik population of $25 \%$ in 2011 , the number of Bantik in the study area was 263. Conceiving the development of coastal areas can be accomplished using ecological, functional, socio-political, cultural and behavioral approaches [11].

\section{Settlement and Community Development Processes}

If we analyze the process of establishing settlements, several factors were involved in determining the location of early settlements including, the Boki River, Ranoasu River, and the coastal areas. These factors are associated with the presence of water as a source of life, while coastal areas were important for defense and easy access to evacuation in case of societal turbulence. The settlement location runs north to south and formed in parallel with the shoreline as a consequence of the linear pattern of urban design along the coast. Residential developments to the east are base on the location of employment in the eastern part of the settlement. Housing is concentrated on one street and terminated at the cemetery to mark the end of the settlement (Fig. 3). Results of the analysis showed that historical roles can be categorized into four groups. These changes do not directly imply local leadership roles reduced by city policy, in which the strength of local communities becomes entangled with variable parameters such as resource communities, community character or unity, physical potential, and local culture. Based on this analysis, it takes an alternative source of community power among the Bantik to collectively act as a counterweight so that the existence of local communities will continue to rebound (Table 1).

\subsection{Retrofit Systems in Japan Development of Spatial Dynamics}

\subsubsection{Analysis of Population Growth}

The population of Manado has grown by $0.9 \%$ in

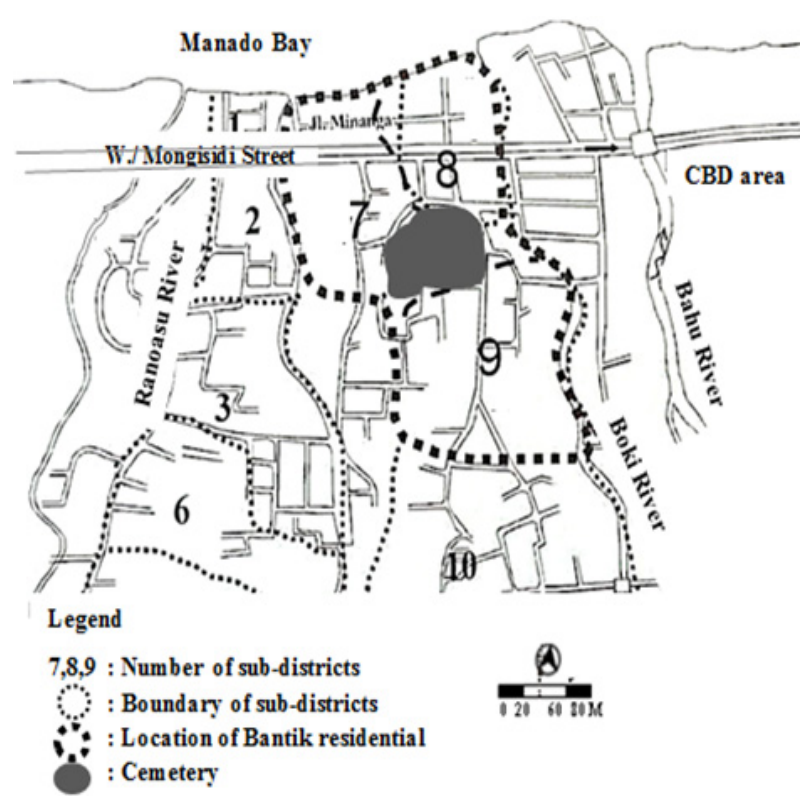

Fig. 2 Location of Bantik residence [1]. 

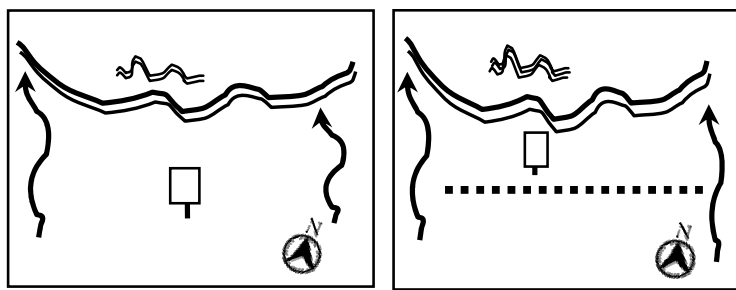

$\sim 1570$

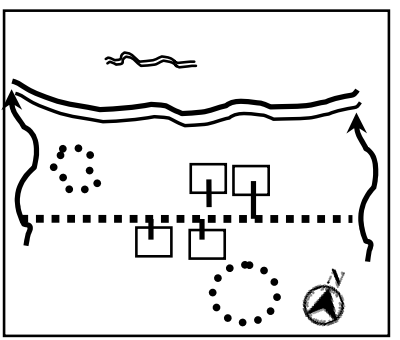

Dutch arrival in the country

Portuguese arrival in the country

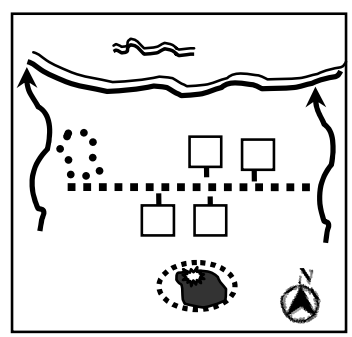

$\sim 1886$

Legend:

々 : River $\sqcup:$ House and orientation

.... : Street :...: Customary land : Cemetery

Fig. 3 The process of settlement establishment.

The last 10 years. This growth is not in line with the growth of Bantik communities in the study area, which has decreased when compared with the overall population at the study site. Up until 2011, the Bantik population made up $25 \%$ of the total population of 1,062 individuals. This decrease is visible on the Bantik distribution map (Fig. 4) of the 1980s, 1990s and 2000s. The Bantik population decline was accompanied by migration out of Manado to the settlements. Most of the decrease in Bantik distribution occurred on the edges of the settlement's main roads. This is related to the accessibility of the functional fabric circulation, which in turn relates to the weakening power of the local minority population.

\subsubsection{Analysis of Regional Growth}

Analysis of regional growth dynamics is based on changes in the function of spatial structure (Fig. 6) and location of the local resettlement (Fig. 7). This is followed by linkage analysis of residence location and time displacement. The biggest change occurred before the year 2000 with a policy of new access in the boulevard area and the boulevard as a commercial area (Fig. 6). Branching time-related changes, we see the development of a local policies territory in the boulevard commercial area, which is in the CBD (central business district) and is easily accessible. Accessibility of functional opportunities can contribute a great deal to developing the spatial settlement. Expansion of the economy functions on the settlement's surface in conjunction with the CBD. Branching also occurred on a second level with the location of settlements behind the cemetery, a zone that will be developed for new housing for non-Bantik migrants.

Based on the questionnaire distributed among the Bantik tribal community in Malalayang as well as field observations, our spatial analysis shows several physical characteristics of the settlement. First, the existence of the coast is only relevant in terms of the neighborhood's physical limits and not to people's

Table 1 Community development.

\begin{tabular}{|l|l|l|}
\hline \multirow{2}{*}{ Variable } & \multicolumn{2}{|c|}{ Analysis } \\
\cline { 2 - 3 } Human resources & $\begin{array}{l}\text { Identification } \\
\text { Based on questionnaires distributed and interview, } \\
\text { undergraduate, 55.6\% high school and 11.1\% middle } \\
\text { school (Fig. 5) }\end{array}$ & $\begin{array}{l}\text { Based on the level of education and employment shows } \\
\text { that they have weaknesses in internal resources and } \\
\text { expertise }\end{array}$ \\
\cline { 1 - 2 } $\begin{array}{l}\text { Unity } \\
\text { Lantik society divided into two generation groups, } \\
\text { namely: young and old generations. Both generations } \\
\text { are likely to have the opposite character }\end{array}$ & $\begin{array}{l}\text { This condition makes the Bantik community } \\
\text { marginalized and reduced by dominant force in the field } \\
\text { of education, location of residence, building appearance, } \\
\text { economic and social role }\end{array}$ \\
\hline $\begin{array}{l}\text { Settlement } \\
\text { environment } \\
\text { (physical) }\end{array}$ & $\begin{array}{l}\text { Start the loss of local culture in the community } \\
\text { Minanga, and beautiful coastal views }\end{array}$ & $\begin{array}{l}\text { Wealth is a potential and bring its own characteristics for } \\
\text { Bantik communities in urban environments }\end{array}$ \\
\hline
\end{tabular}




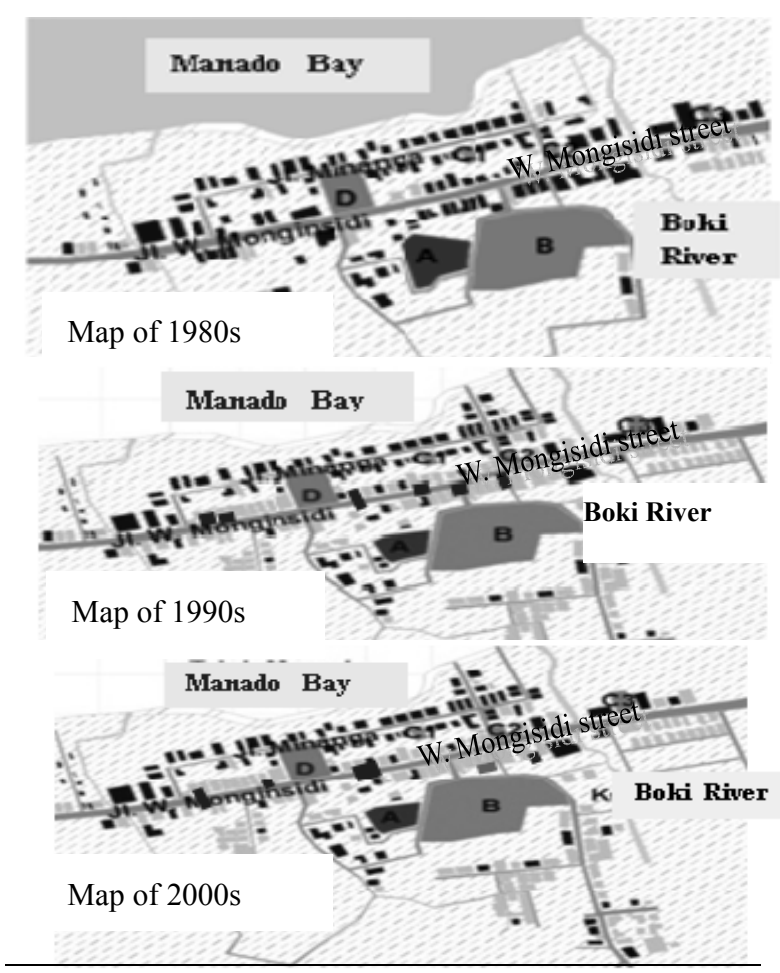

Approximate number of Bantik family buildings

\begin{tabular}{lc}
\hline 1980s : $86 \quad 1990$ s : 65 & 2000s : 58 \\
\hline Legend: & \\
A : Exclusive space $\quad$ B & : Cemetery D : Field \\
: Bantik family & : Non Bantik family
\end{tabular}

Fig. 4 Distribution of Bantik families.

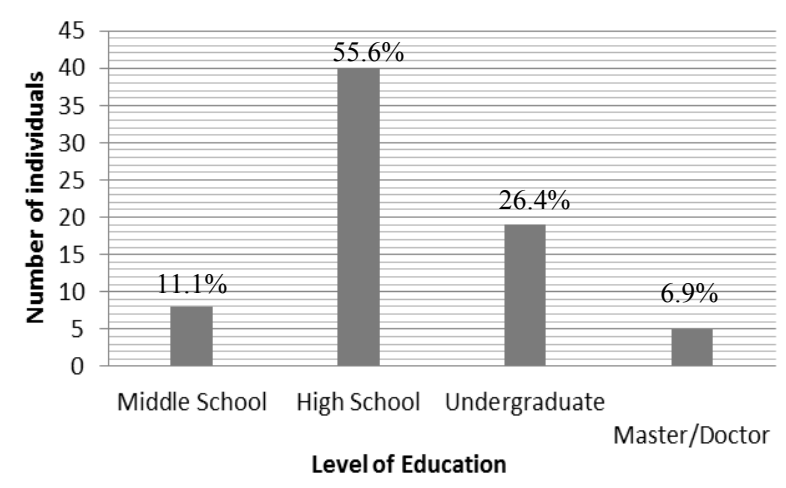

Fig. 5 Level of education among the Bantik.

livelihoods. This is clear considering that fishermen today and in the past are unable to earn a living. Currently, $68.9 \%$ of these individuals work in the public sector and $31.1 \%$ are employed as civil servants. The second characteristic involves street level activities and in particular, kinship, since local

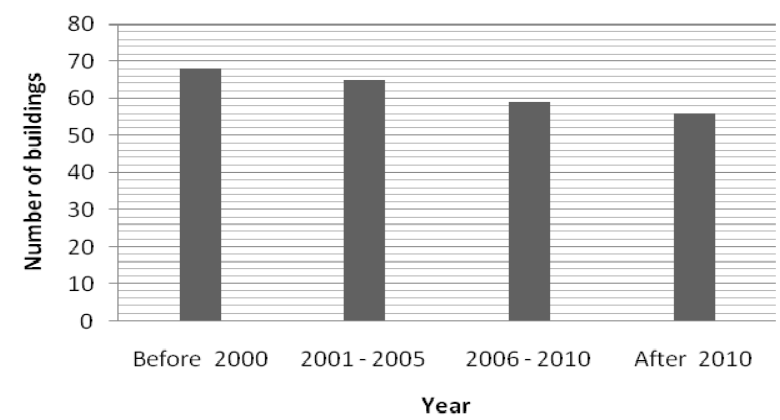

Fig. 6 The number of changes in the building function, from residential to commercial.

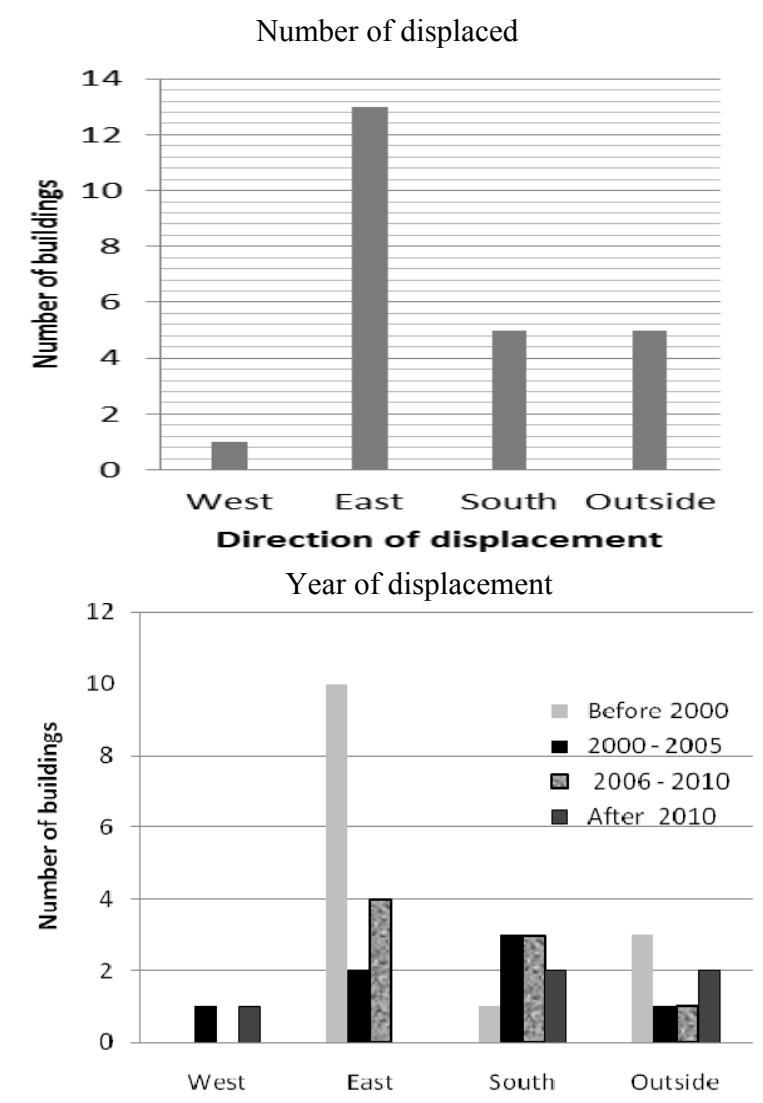

Fig. 7 Resettlement of Bantik families.

communities are inextricably inter twined. In the context of kinship, infinite open space in front of the residential house spills into the street as public space where some activities are carried out, for example along Minanga Road. This location is used as a community gathering space, especially for women and as a playground for children. These activities take place at all times of the day. For young children, the space was used starting in the afternoon after school 
until the late afternoon or early evening (Fig. 8).

Communal land is the third characteristic of a Bantik settlement. Based on our questionnaire and interviews, $72 \%$ of the respondents reported that customary land is based on wealth. Thus, Bantik tribal communal land is used for the common good. This land is managed by the Bantik tribal community organizations and used for public purposes. Regulations apply to managing the asset and are defined by norms or local customary laws prevailing in the society. The function of these lands can be classified into two groups:

(1) Social function: This is dedicated to all Bantik for ease in using the facilities that were/are built on customary land. Locations associated with these functions include cemeteries;

(2) Cultural functions: This is a venue or gathering space associated with communal activities.

\subsubsection{Analysis of Spatial Expression}

This topic emphasizes spatial changes that lead to spatial activity and expression. A shift is seen in the spatial expression of changes in the function of a particular place. Morphological changes of the settlement area are dominated by changes in the building's function or the quality of buildings and the environment. The most prominent differences that occurred involve size, shape, building structure, and the quality of buildings owned by the public and non-Bantik (Table 2). The size of Bantik-owned buildings are between $40-80 \mathrm{~m}^{2}$ and have residential functions. Of the non-Bantik owned property, the area covered more than $80 \mathrm{~m}^{2}$ for commercial buildings, which had mixed functions. These differences are based on the background, activities and livelihoods of the owners. On the other hand, the spread of the local residential community barely shows any significant development, because it spread in areas behind the settlements or outside of the settlement area due to the displacement of dwelling sites. Structural space was formed by local activities or public space. This could include open fields as gathering space built on the customary lands, cultural

sites (e.g., Stone Niopo or Crocodile Rock), “exclusive space", cemeteries and Ake Minanga in the Bantik language. Local people believe the location has the power of the culture (Fig. 9).

\subsection{Dynamics of Change}

\subsubsection{The Change of Regional Functions}

The Based on statistical data from samples taken under the category of "transfer of land ownership along Mongisidi Street," 37.14\% of the structures were turned into commercial buildings, 5.14\% to social functions, and $57.14 \%$ a combination of commercial and residential functions (Fig. 10).

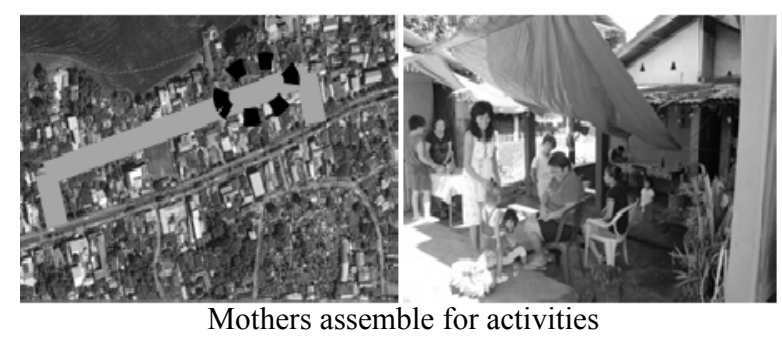

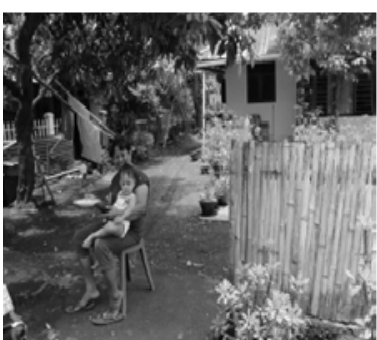

Mother feeding her child Legend:

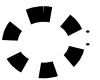

Location of activities

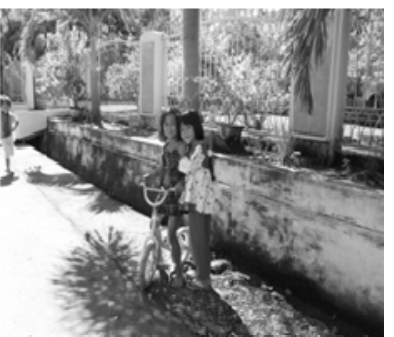

Children's play activities

ig. 8 Expansion of communal activities.

Table 2 Building expression.

\begin{tabular}{lll}
\hline Building & Bantik's building & Non Bantik's building \\
\hline Form & Housing typology & $\begin{array}{l}\text { Commercial building } \\
\text { typology }\end{array}$ \\
& Function: residence & Function: residence and \\
& & store \\
\hline Size & $45-80 \mathrm{~m}^{2}$ & $>80 \mathrm{~m}^{2}$ \\
\hline
\end{tabular}




\begin{tabular}{|c|c|c|}
\hline Location & Structure of space & Value of location \\
\hline 1. Field & Public open space & $\begin{array}{l}\text { Unifying and culture } \\
\text { space }\end{array}$ \\
\hline 2. Cemetery & Public open space & Social space \\
\hline $\begin{array}{l}\text { 3. Niopo/crocodile } \\
\text { stone }\end{array}$ & Public open space & Culture space \\
\hline 1. Exclusive space & Private open space & Culture space \\
\hline Ake Minanga & Open space & Culture space \\
\hline
\end{tabular}
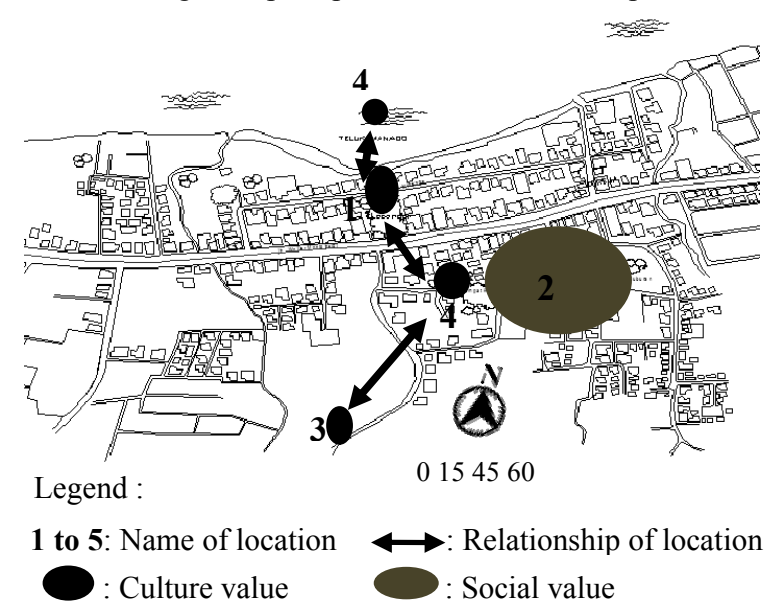

Fig. 9 Sites with local cultural value.

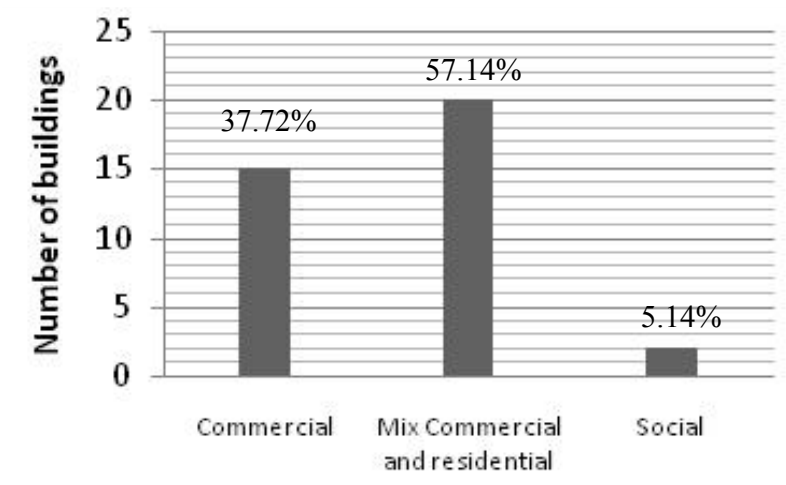

Fig. 10 Building functions.

Changes in building function occurred through the transfer of ownership from the Bantik to non-Bantik.

The data indicate several categories of regional changes. First, the building function changed; residential buildings were turned into commercial ones. This change was accompanied by a change of ownership and structural shape (Fig. 11). The model consists of different building functions, including residential mixed with commercial, residential with occasional commercial and entirely commercial (Fig. 12).

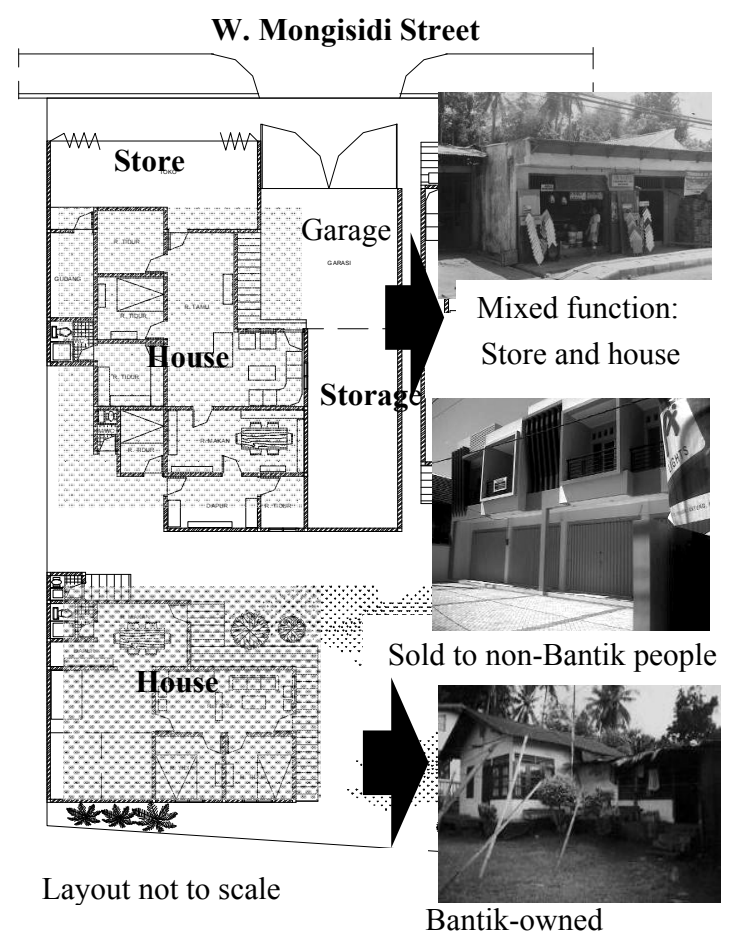

Fig. 11 Process of change in building function.

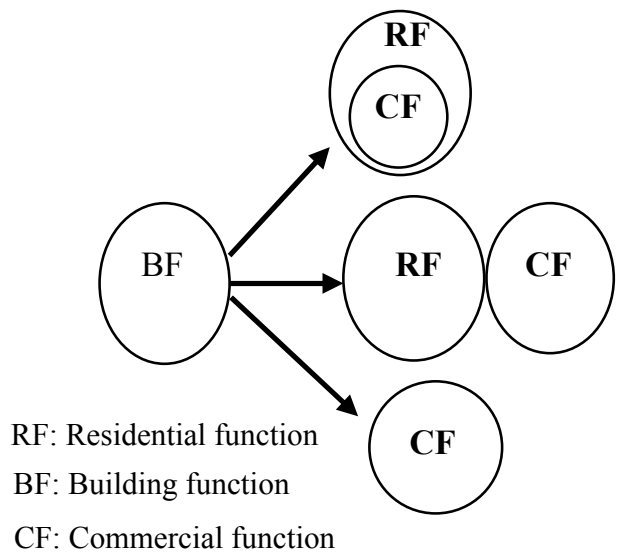

Fig. 12 Model of changes in buildings.

Second, change of ownership occurred. The expansion of land ownership change meant that public access along the coast was interrupted by the building's presence so that free movement along the coast was lost (Fig. 13).

The third change involved space. Private space was transformed into public space in the western settlements, while public space was turned into private space in the eastern part. 


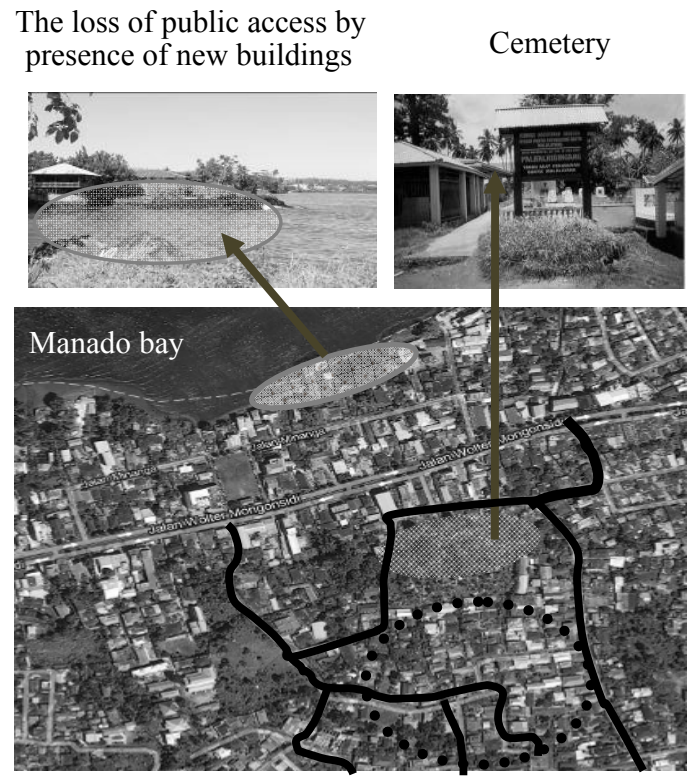

Legend:

$$
\text { L Public access } \quad \because \bullet: \text { : New settlement }
$$

Fig. 13 Expansion of economic interests.

\subsubsection{Urban Policy}

The existence of a facility with provincial outreach and close proximity to the city center has high economic value in the Malalayang region. Based on the General Regional spatial Plan 2006-2016 for Manado City, this facility was the primary care center of Malalayang, which included services for housing and settlement development, reclamation and coastal recreation, and health. Widely available vacant land was used by the property investor, resulting in population growth that could be controlled and a reduction in the quantity of tribal people in
Malalayang Bantik which local communities. This brought spatial pressure on the local community along with the unpreparedness of resources, which resulted in psychological and economic pressures. Adapting to the environment required great wisdom, especially when it involved unavoidable changes.

\subsubsection{CBD's Influences on the Settlement Area}

The sustainability of space between the CBD and settlement requires limiting the growth of commercial space into settlements. The direct effect of growth occurred in the physical space of the settlements, especially in the main corridor on the first level precisely in the settlement area. Space along the main corridor used for economic purposes was supported by the availability of access roads linking the Trans-Sulawesi between provinces, with branching settlements as a forerunner to the function (Table 3). The CBD's effect is also seen in the commercialization of space. This is characterized by the appearance of architecture blending commercial building typologies such as shops and merging them with residences (Fig. 14). An increase in activity and density of transportation lines is seen in terms of

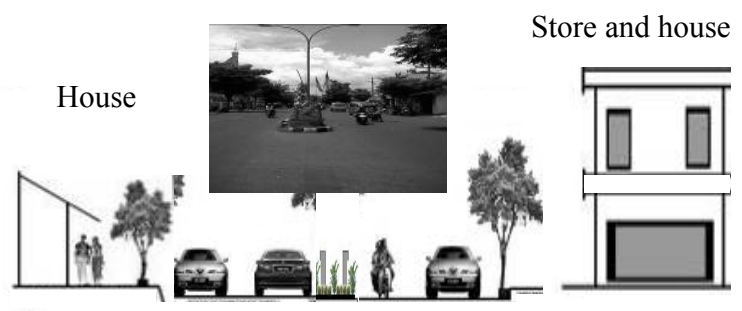

Fig. 14 The nuanced commercial visualization settlement.

Table 3 Impact of CBD effect.

\begin{tabular}{ll}
\hline Variable & Impacts \\
\hline \multirow{2}{*}{ Visualization of settlement } & $\begin{array}{l}\text { There is seepage commercial space into residential areas } \\
\text { An area function compounds between residential areas with commercial areas } \\
\text { Increasing the number of commercial buildings in the settlements }\end{array}$ \\
\hline \multirow{3}{*}{ Access (main road) } & $\begin{array}{l}\text { Ease of community sector interaction between sub-regions } \\
\text { Ease of attainment of the settlement location } \\
\text { Interest in the community outside of the residential location } \\
\text { The increase in the volume of vehicles and passengers that pass through residential area }\end{array}$ \\
\hline \multirow{2}{*}{ Economic and lifestyle } & $\begin{array}{l}\text { Increasing the number of commercial buildings in the settlements } \\
\text { Increasing the economic value of land }\end{array}$ \\
& $\begin{array}{l}\text { Urban oriented } \\
\text { Increased needs of life }\end{array}$ \\
\hline
\end{tabular}


economic activity, health, and daily life. Fusions occurred between structure with a commercial look but the feel of settlements, which are characterized by the presence of houses on the sides of commercial buildings.

\subsubsection{Public Mindset}

The spatial behavior among Bantik tribal communities involves either individual or social processes. Individual processes are more influenced by a strong personality, while social processes are influenced primarily by the environment, urban development, and educational background, resulting in tolerance of the group's behavior. A shift in the public's mindset begins with changes in the communal character of the young generation, whereas the older generation ( $\geq 60$ years of age) is more subjective. Bantik population numbers are declining (as of 2011, approximately 25\%). Factors behind the change of mindset included a shift to living in the back of a dwelling or in the outside settlements of Bantik society. The urban lifestyle was also an influence.

\section{Discussion}

This analysis showed that the spatial dynamics of change become difficult to avoid, since they are related to various factors such as development of the economic zone of the city, urban policy, and the needs of local communities. Indeed, spatial changes in the Bantik neighborhoods began with the entry of the non-Bantik zone as a result of the development of residential areas, city policy and commercialization in strategic settlement areas. This resulted in imbalanced growth between the Bantik and non-Bantik populations. The $\mathrm{CBD}$ had a very strong influence by making various changes, such as moving Bantik residential locations through the transfer of land ownership from Bantik to non-Bantik people. This accelerated the distribution of the settlement among fewer Bantik, followed by changes in the function of a building from residential to commercial. Changes in outlook and lifestyle were also influenced, so they occurred both in physical neighborhoods as well as society.

The commercialization of the area was undertaken for the benefit of Bantik community's economy but it has not been followed by an increase in internal resources, such as improved levels of education and skills. This is closely related to job opportunities that greatly affect the economic improvement of the Bantik community so its citizens are not marginalized in settlements. Economic improvement will be established by the existence of community, so that people can live, changes can be anticipated, and settlements can be maintained. Indeed, the characteristics of a regional settlement based on cultural factors can still be found but such agreements are less able to withstand changes. This is due to the strong influence of the potential cultural development of the city. In fact, preserving the unique Bantik culture is in the Bantik community's interest. The uniqueness of the settlement's location and culture-based activities will be strengthened in local residential character. This wealth of potential for the community is one that the city must maintain.

\section{Conclusions}

Spatial changes occurred in the Bantik tribal communities in Malalayang as the result of a combination of factors in the community, including urban development, commercialization and its impact on the CBD area, and a lack of internal resources. Two main spatial changes occurred in these communities. The first one involved changes in the visualisation of the area, especially in settlement's main corridor. This changed the function of a building from residential to commercial function. This change was influenced by the factors such as the continuity of commercial space, accessibility, and economic value of the region. The second group of changes were sociocultural and caused by factors of urban life. These changes tended to create a Bantik society that 
was a minority population in the settlements. Building ownership was only in strategic locations and residence location was marginalized. Adjustments to various changes can be made by maintaining kinship in local communities, maintaining a potential location based on culture and an increase in skill base and economic support. It is also necessary to adjust to life's necessities and people's mindset. Thus, future spatial changes that occur can be anticipated so that residential location with a local character and existence of indigenous Bantik tribal people can be maintained. This study is a useful exploration into protection and sustainability of local communities in a city that experienced the pressure of urban development. The results of this study benefit the cultural wealth of the city.

\section{References}

[1] P.P. Egam, N. Mishima, W.S. Subroto, Impact of urban development to coastal Bantik settlement in Malalayang, Indonesia, in: Proceedings of the 8th International Symposium ILT, Indonesia, 2011, pp. 554-560.

[2] P.P. Egam, W.S. Subroto, The spatial change pattern in Bantik community, case study of Malalayang one,
Manado city, north Sulawesi, Master's Thesis, Gadjah Mada University, Yogyakarta, 2003.

[3] H.B. Palar, Minahasa Old Face, Yayasan Gibon, Jakarta, 2009.

[4] S. Sumolang, History (Ancestors) of Bantik, Buletin KURE 5 (5) (2010) 51-56.

[5] N. Grafland, Minahasa, Yayasan Parahita, Jakarta, 1991.

[6] V. Thanousorn, Spatial Development of Lao urban dwelling along the Mekong river, Journal of Asian Architecture and Engineering 9 (2) (2010) 403-407.

[7] P.P. Egam, N. Mishima, A planning approach of population movement for local coastal bantik community, in: Proceeding of International Conference on Convergence Content, Slovak Republic, 2012, pp. 101-102.

[8] S.H. Sohn. Spatial analysis of urban structure changes in Korean Mega-Cities, Journal of Asian Architecture and Engineering 9 (1) (2010) 201-206.

[9] S. Ombeni, A. Deguchi, Transformation of residential units into commercial spaces in the central business district of Dar es Salaam, Tanzania, Journal of Asian Architecture and Engineering 9 (2) (2010) 403-407.

[10] O. Rumi, Deterioration of heritage by urbanization in Mekelle, Ethiopia, Journal of Asian Architecture and Engineering 10 (2) (2011) 335-342.

[11] Djunaidi A. and Basuki M.N, Coastal development planning, Journal of Environment Technology 3 (3) (2005) 225-231. 